\title{
Duty of the Rabbi
}

\author{
Undated
}

This undated fragment captured a key credo of Leonard Beerman's rabbinate. It came not from his own pen, but from that of the towering American Orthodox rabbi and scholar Joseph B. Soloveitchik. Beerman reports that Soloveitchik recalled that his own grandfather defined the vocation of the rabbi as caring for the poor and exploited. The fact that the source was neither an ancient prophet nor a Reform rabbi but a modern Orthodox sage lent added credibility to this social justice imperative.

As for the duty of the Rabbi, I prefer the opinion of the grandfather of one of our country's foremost orthodox rabbis, Rabbi Joseph Soloveitchik, who relates that when his grandfather was asked to define the peculiar calling of the Rabbi, he answered that it was "to protest the neglect of the lonely and the abandoned; to protect the dignity of the poor; and to save the exploited from the exploiters."

\section{COMMENTARY BY RABBI RICHARD LEVY}

Rabbi Soloveitchik wrote "The Lonely Man of Faith" — and this was Leonard's faith: on one level, to eschew loneliness and seek out spokespeople for the poor and exploited, to denounce the exploited and to cry out for peace. For Leonard, loneliness and faith were two qualities permanently in tension in his life: he never expected to be "popular," yet he felt wounded by anyone who was moved by his words to disagree with him-he felt he had alienated his opponent. He opined that you can't be a successful rabbi unless at least one person walks out on a sermon of yours-and yet he claimed he was unsuccessful because there were still lonely and abandoned and poor and exploited people in the world. Did Leonard feel 
"called" to be a rabbi? He felt called to work against injustice, yet he knew that to work against it out of a Westside Los Angeles synagogue was a little ironic. In the 1960s, when "worker priests" would go out into the streets and the fields to witness with their congregants where they were, Leonard observed that when he would have lunch with congregants in their Bel-Air offices, he was being a worker priest too. And he was: he would speak with them about conditions in the world, and when he returned to Leo Baeck Temple he would contact his African American colleagues and his Episcopal colleagues and invite them to speak at the temple so that he could bring the world into Bel-Air, and from the inspiration of the beautiful sanctuary whose design he supervised, his flock could compare the differences between their lives and those of the oppressed, and contemplate seriously how they might bridge the gap. 